\title{
Resilience and adaptability of traditional healthcare systems: a case study of communities in two regions of Brazil
}

\author{
${\text { Sofia } \text { Zank }^{1}, \text { Luciana Gomes de Araujo }}^{2}$ and Natalia Hanazaki $^{1}$
}

\begin{abstract}
The traditional healthcare systems (THS) of communities in two different regions of Brazil were investigated through the lens of social-ecological resilience, assuming that the resilience of THS and of the communities influence each other. We analyzed what has sustained and changed in the trajectory of THS of different rural and coastal communities in Brazil during the last seven decades, focusing on the domains of social biodiversity (especially on plant diversity for medicinal use), health practices learning, and social organization. The THS analyzed refer to three rural communities in northeastern Brazil, and three Quilombola communities on the southern coast of Brazil. Data were obtained through participatory methods, interviews, and secondary sources. The main drivers affecting the THS were the (1) development of national and regional infrastructure, (2) access to public healthcare, (3) implementation of protected areas, and (4) recognition of Quilombola territories (Quilombos). The components of social biodiversity, learning, and social organization contributed to the adaptive capacity and resilience of the systems through the continuity of knowledge transmission, use of local biodiversity for healthcare, request for local specialists, recovery of cultural practices, and institutional development of local organizations and partnerships. Challenges concerning the resilience of the THS are explained by the urbanization processes, restriction of access and use of some native plants, decrease in economic dependence on local biodiversity resources, and the need to improve social capital. After assessing the factors affecting the resilience of THS, we recommend actions that could enhance socialecological resilience in different communities and under different situations.
\end{abstract}

Key Words: ecological knowledge; ethnobotany; health; social-ecological systems

\section{INTRODUCTION}

Resilience thinking has been widely used as a conceptual and applied framework to analyze changes and crises in socialecological systems (Berkes et al. 2003, Chapin et al. 2009, Olsson et al. 2014). More recently it has addressed dimensions of social aspects of the mechanisms of adaptability (or adaptive capacity) and transformability of social-ecological systems (SES), such as social learning, integration of knowledge systems, social networking, agency, power, and innovation (Folke 2006, Folke et al. 2010, Olsson et al. 2014, Stone-Jovicich et al. 2018). Although resilience and adaptability can be addressed at the community level (Berkes and Jolly 2001, Marschke and Berkes 2006, Goldstein 2008, Berkes and Ross 2013, Prado et al. 2015, Armitage et al. 2017a), however different communities represent distinct SES and therefore may unveil specific sets of patterns, mechanisms, and dynamics, which are essential to understand resilience and adaptability in diversified situations.

Resilience is defined as the capacity of a system to absorb disturbances and reorganize while undergoing change and maintaining essentially its structure, function, feedbacks and identity (Walker et al. 2004). Individuals, a whole community, part of the ecosystem, or integrated elements of a system will be challenged to use their adaptive capacity when the capacity of a system to absorb disturbance is exceeded (Armitage et al. 2017b). As a core element of social-ecological resilience, adaptability is the ability of the SES to learn and respond to endogenous processes and external drivers, maintaining its domain and trajectory (Walker et al. 2004, Folke et al. 2010). Innovations created at the community level are a significant aspect of adaptive capacity because it may prevent undesirable systems' trajectories (Olsson et al. 2014). For example, local innovations have the potential to shift livelihoods and increase adaptive capacity in the face of crises, such as when coastal fishers' communities broaden their economic activities adopting tourism-based activities (Prado et al. 2015).

Berkes and Ross (2013) developed an integrated approach to community resilience, considering that although communities do not control all the forces that affect them, they possess the skills to change many conditions that could increase resilience and adaptability. In this approach, adaptive capacity and learning in SES are integrated with the identification and improvement of community strengths, with emphasis on people-place connections, systems of knowledge, values, beliefs, and leadership. In this way, both collective and individual capacities, on the one hand, and systems properties, on the other, are highly important to enhance resilience at the local level through agency and self-organization. Agency here is understood as involving individuals, organizations, or networks (Olsson et al. 2014) whereas self-organization is activated by elements such as social identity, social capital, community infrastructure, leadership performance, knowledge production, and learning processes (Berkes and Ross 2013).

In this study, traditional healthcare systems (THS) are complex adaptive systems at the community level. They are originally mediated by local health specialists (e.g., healers, midwives, and medicinal plant experts) and are rooted in knowledge and practices of traditional medicine, although they can incorporate novelties. Traditional medicine is defined as "the sum total of knowledge, skills and practices based on the theories, beliefs and experiences indigenous to different cultures that are used to maintain health, as well as to prevent, diagnose, improve or treat

${ }^{1}$ Laboratory of Human Ecology and Ethnobotany, Federal University of Santa Catarina, ${ }^{2}$ Center for Studies and Environmental Research, State University of Campinas 
physical and mental illnesses" (WHO 2008). Knowledge is conceived as the product between local ecological knowledge accumulated over time and learning from errors and crises. This is an evolutionary process in which local ecological knowledge is a result of adaptive and transformative responses to environmental, social, and cultural pressures, changes, and crises (Berkes and Turner 2006, Gómez-Baggethun et al. 2010).

As placed-based systems, THS respond to the influence of internal and external factors (or drivers of change) based on their own mechanisms of adaptation. For example, ecosystem services at the community level play an important role as endogenous factors generating multiple benefits such as medicinal resources (e.g., plants), recreation, and water quality (Zank et al. 2015). The status of these services directly affects the capacity of THS to respond to changes and crises. In the same way, national policies improving citizens' access to hospitals and industrialized medicine are products of exogenous factors affecting the dynamics and resilience of THS at the local level. Furthermore, endogenous and exogenous factors affecting THS interact with each other producing additional emergent responses and patterns that can trigger or reinforce the current trajectory of THS. Studying THS through the lens of resilience thinking helps to understand how specific social and environmental factors acting on the structure and dynamics of THS affect livelihoods and individual choices at the community level (Ladio and Lozada 2009, Ferreira Júnior et al. 2013).

Berkes and Ross (2013) discussed the correspondence between health and resilience of communities and their surrounding environment. Inspired by their arguments, we analyzed the resilience and adaptability of communities' THS based on two sets of assumptions. First, resilient THS benefit from communities with high social biodiversity, active and continuous learning processes, and strong social organization. Second, there is a positive feedback between resilient THS and the healthy communities attached to them.

Under the social-biodiversity component, we focused on the diversity of known medicinal plants, which is a result of the integration of ecological and social aspects, such as plant richness and local knowledge systems, in a continuous process of development, change, and evolution. In this case, if a specific plant falls under disuse due to loss of natural habitats or because it was replaced by industrial medicines, then part of the THS is affected in at least its diversity component. Learning processes in THS refer to knowledge production and transmission and acknowledging local specialists. The aspects of social organization comprise the existence of empowered community leaders, well-developed community-based organizations (CBOs), and partnerships with external organizations.

Our focus is to understand what has sustained and changed in the trajectory of THS of different rural and coastal communities in Brazil along the last seven decades. The specific objective is to discuss in what way changes occurring in the domains of social biodiversity, health-practices learning, and social organization of the studied communities affect the adaptive capacity of THS. Because changes and responses in the studied THS were triggered by economic, social, and environmental factors, we posed two guiding questions: (1) What are the main economic, social, and environmental factors (or drivers of change) affecting THS in the last 75 years (1940-2015)? and (2) What were the responses to these factors in the THS concerning social biodiversity, healthpractices learning, and social organization in the studied communities? We assume that the resilience of THS is related to its very specific context and complexity. Therefore we maintained our focus on their specific social-ecological aspects with no specific intent to assess the medical efficacy of THS.

\section{Social biodiversity, health-practices learning, and social organization as components of traditional healthcare systems (THS)}

Resilient systems are characterized by high ecological diversity (Berkes 2005) and different and overlapping ecological functions, both capable of improving the capacity of a system to respond to disturbances (Levin 2000, Folke et al. 2004). Social dimensions of THS, such as local knowledge and cultural manifestations are linked to ecological diversity as humans actively modify the environment and adapt to it (Berkes 1999, Davidson-Hunt and Berkes 2003). We consider that the social biodiversity (focusing on the diversity of medicinal plants) in a community is determined by the richness of known medicinal plants, autonomy in obtaining these plants, economic dependence on plant, and cultural importance of local ecosystems (see also Ladio and Lozada 2009, Berkes and Ross 2013, de Boef et al. 2013). The higher the diversity of known plants and autonomy in obtaining them, the greater is the extent of adaptive responses to disturbances and changes. The autonomy to obtain medicinal plants means a guarantee to access the best resources for illnesses' treatments. It is maximized depending on whether healers can count on two strategies: extraction and cultivation. When the two strategies are available, healers can manage risks, such as local extinction of a wild species, prohibition of collecting, or scarcity of water for cultivation.

The economic dependence on plants is a recurrent feature in communities' livelihoods across the world. It favors the production and maintenance of local ecological knowledge (see, for example, targets 12 and 13 of Convention on Biological Diversity 2010) by keeping people in continuous interaction and learning with their natural and agricultural environment. From this, economic dependence on plants can be considered as a component of the THS affecting the resilience of these systems.

The last factor presented as determinant for medicinal plant diversity in THS is the cultural importance of local ecosystems. The maintenance of knowledge and use of medicinal plants depends on the cultural importance that the wild and managed ecosystems have to communities. When communities recognize and protect ecosystems as a source of cultural values and benefits to their health and well-being, it also functions as a resilient property connecting them with the natural environment (Zank et al. 2015, 2016).

Learning is an important mechanism for community resilience becausea it nurtures social cohesion, sense of community, the development of individual and group capacities, and innovations (Armitage et al. 2008, Berkes and Ross 2013). Learning about medicinal plants is a necessary condition for THS to exist and evolve, as well as the capacity to produce different responses to social and environmental uncertainties. Learning processes can be individual or collective, both being important components of THS. 
Individual learning processes are centered on the production and transmission of specialized knowledge. Knowledge transmission at the individual level can be vertical, horizontal, oblique, or diffuse (Cavalli-Sforza et al. 1982). In vertical transmission, information flows between two individuals of different generations of the same kinship. Horizontal transmission takes place between two individuals of the same generation, and oblique transmission occurs between two individuals of different generations who are not related. In diffuse transmission, knowledge is transmitted through other means, such as books, television, and the Internet. Vertical transmission tends to be highly conservative, and innovation is unlikely if no other transmission path is present in the community (Cavalli-Sforza et al. 1982, Hewlett and Cavalli-Sforza 1986). It is also important to consider that these forms of transmission occur through multistage models in which vertical transmission in childhood loses pre-eminence for horizontal and oblique models such as the subjects' age (Reyes-García et al. 2016). In addition to transmission, it is also important to consider that knowledge continues to be produced and innovated based on local demands and on the relationship with natural ecosystems.

Collective learning refers to social learning based on collective processes of iterative reflection with the sharing of experiences, ideas, and social contexts. These processes are driven by the community or by exogenous problems, such as market pressure or regulations related to natural resource use (Armitage et al. 2008). It is important to highlight that both processes of individual and collective learning are based on cooperation, favoring the adaptation and evolution of human societies (Boyd and Richerson 2009, Boyd et al. 2011). Requesting and appreciating local health specialists is a binding requirement for the perpetuation and evolution of learning systems. Making these specialists valuable for the community is a motivation for them to give continuity to practices and innovations and opens up opportunities for young people to take up this role in the future.

Empowered community leaders, well developed CBOs, and partnerships with external organizations are social and institutional factors capable of enhancing community resilience because they lead to agency and self-organization (Berkes and Ross 2013). Because THS are systems integrated in communities, community strengths may influence resilience and adaptive capacity of THS. For example, improvements driven by welldeveloped CBOs such as accessing funds to encourage community learning processes can be seen as a resilience-building strategy (Berks and Ross 2013, de Araujo et al. 2017) capable of influencing adaptability of THS. In the same way, empowered leaders influence local organization and the establishment of partnerships. As individuals and CBOs build new capacities, innovate in partnerships, THS indirectly gain in terms of resilience and adaptive capacity. The more organized the community is, the greater its ability to cope with changes that affect health and wellbeing.

\section{STUDY AREA}

Six case studies were conducted in northeastern and southern Brazil. In the northeastern region, case studies were conducted in the rural communities of Macaúba, Cacimbas, and Maracujá, situated in Chapada do Araripe (Zank et al. 2015). The other three case studies were carried out in Quilombola communities of Morro do Fortunato, Santa Cruz, and Aldeia, situated in the southern coast of Santa Catarina State (Ávila et al. 2015, Zank et al. 2016; Fig. 1). Quilombola are Afro-descendant populations that have their territory rights guaranteed by the Brazilian Constitution and federal laws.

Fig. 1. Study area showing the three rural communities of Chapada do Araripe, northeastern Brazil (Macaúba, Cacimbas, and Maracujá) and the three coastal Quilombola communities, southern Brazil (Morro do Fortunato, Santa Cruz, and Aldeia).

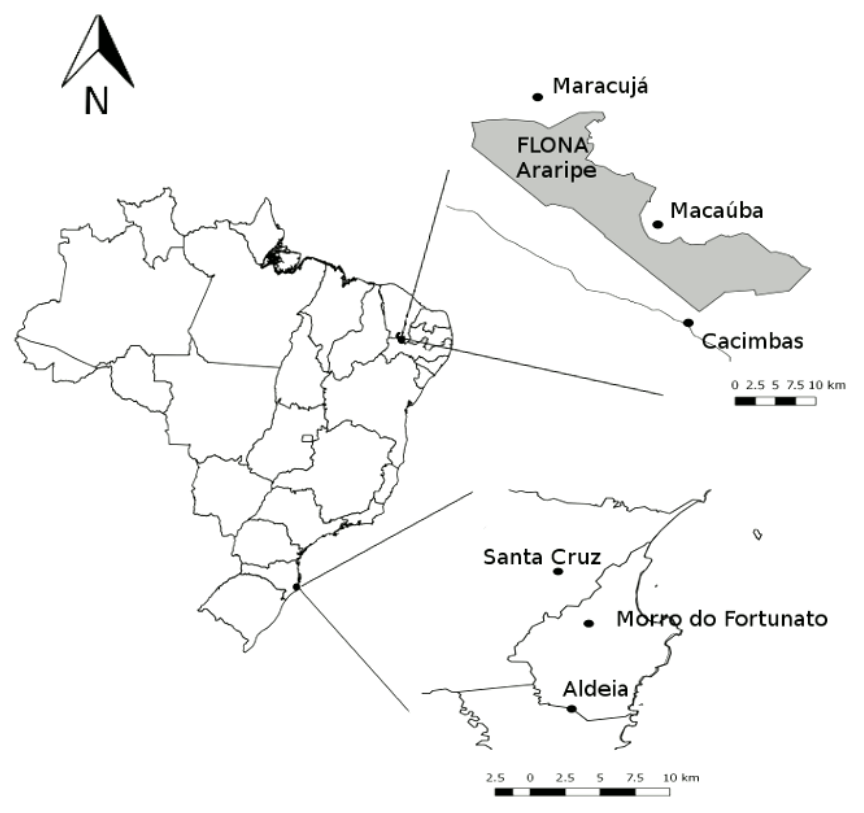

Chapada do Araripe is located in the semiarid Caatinga, which is characterized by different types of savannah vegetation: cerrado (Brazilian savanna), cerradão (wooded savanna), humid forest, and carrasco (steppe; da Costa et al. 2004). The Caatinga ecosystem is notable for its ecological and cultural diversity (Oliveira et al. 2012, Baldauf and Santos 2013, Lozano et al. 2013, Sousa Júnior et al. 2013), but also challenged by water scarcity and low indices of well-being.

In Chapada do Araripe, economic activities include family agriculture, livestock, and plant extraction. There are two protected areas (PA) in the region: Chapada do Araripe Environmental Protected Area and Araripe National Forest. The communities of Macaúba, Cacimbas, and Maracujá are 20 to 40 kilometers away from each other. All of them have at least an elementary school and a Catholic church. Macaúba and Cacimbas each have a health care center, and people from Maracujá use a health care center five kilometers away from the community. Health care centers are small facilities that offer basic healthcare to the locals and are maintained by the government (Table 1).

The studied Quilombola communities are situated in the southern coastal Atlantic Forest. Morro do Fortunato is located on a hillside surrounded by native vegetation, i.e., dense forests and restinga (moist broadleaf forest) vegetation. The community of Santa Cruz is spread along an unpaved road characterized by 
Table 1. Social and environmental data of the studied communities.

\begin{tabular}{|c|c|c|c|c|c|}
\hline Region & Ecosystem & Community & $\mathrm{N}^{\circ}$ of families & Rural/ Urban & Livelihoods \\
\hline $\begin{array}{l}\text { Chapada do Araripe, } \\
\text { northeastern Brazil }\end{array}$ & Semiarid Caatinga & $\begin{array}{l}\text { Macaúba } \\
\text { Cacimbas } \\
\text { Maracujá }\end{array}$ & $\begin{array}{l}275 \\
260 \\
500\end{array}$ & Rural & $\begin{array}{l}\text { Extraction and } \\
\text { agriculture }\end{array}$ \\
\hline $\begin{array}{l}\text { Quilombos, Coastal } \\
\text { southern Brazil }\end{array}$ & Atlantic Forest & $\begin{array}{l}\text { Morro do Fortunato } \\
\text { Aldeia } \\
\text { Santa Cruz }\end{array}$ & $\begin{array}{l}30 \\
35 \\
30\end{array}$ & $\begin{array}{l}\text { Rural } \\
\text { Urban } \\
\text { Rural/ Urban }\end{array}$ & $\begin{array}{l}\text { Urban jobs, agriculture, } \\
\text { and livestock }\end{array}$ \\
\hline
\end{tabular}

rural and urban aspects, whereas Aldeia is an urban community. The main source of income for most people of Morro do Fortunato, Santa Cruz, and Aldeia is obtained from urban jobs in the neighboring cities of Paulo Lopes and Garopaba. Until the 1970s, these communities' livelihoods were mainly based on subsistence agriculture and small-scale fishing (Ávila et al. 2015). Because there are no health centers, schools, or churches within the communities, people drive to the nearby cities to access public health and educational services.

\section{METHODS}

Data collection was based on participatory workshops, semistructured interviews, and secondary data (published and released information). They were collected to describe the history, present social and environmental aspects, and use and management of plant biodiversity of the two regions (Araripe and Quilombos) and related THS. We did six community workshops in both regions with the oldest people and community leaders of each community. They were based on the participatory techniques of timeline building, historical chart, and Venn diagram (de Boef and Thijssen 2007). In each workshop, we sought to (1) characterize the local traditional medicine and changes that have occurred over the last 75 years, and (2) identify individuals, groups, and organizations linked to the THS in each community. Interviews with local health specialists in the two sets of communities (Chapada do Araripe, $\mathrm{n}=66$; Quilombos, $\mathrm{n}=$ 22) complemented information about changes in traditional medicine use (Zank and Hanazaki 2017). Local specialists of Chapada do Araripe (27 in Macaúba, 18 in Cacimbas, and 21 in Maracujá) were also interviewed to collect data on (1) known plants, (2) sources of medicinal plants, and (3) individual learning about medicinal plants. The same data were collected through interviews with 184 adults in the Quilombola communities (63 in Fortunato, 65 in Aldeia, and 56 in Santa Cruz; see Zank et al. 2015 and Ávila et al. 2015 for more details).

Social biodiversity with focus on local plant diversity encompasses: (1) richness of medicinal plants; (2) autonomy to obtain medicinal plants; (3) economic dependence on local biodiversity; and (4) cultural importance of local biodiversity (detailed procedures are described in Ávila et al. 2015, Zank et al. 2015, 2016, Zank and Hanazaki 2017). The health-practices learning component is separated in (1) individual learning about medicinal plants, (2) collective learning about health, and (3) acknowledging local specialists. Social organization covers the occurrence and interactions of empowered community leaders, community-based organizations (CBOs), and external partners (Fig. 2).
Fig. 2. Components of social biodiversity, health-practices learning, and social organization affecting resilience and adaptive capacity of studied traditional healthcare systems (THS).

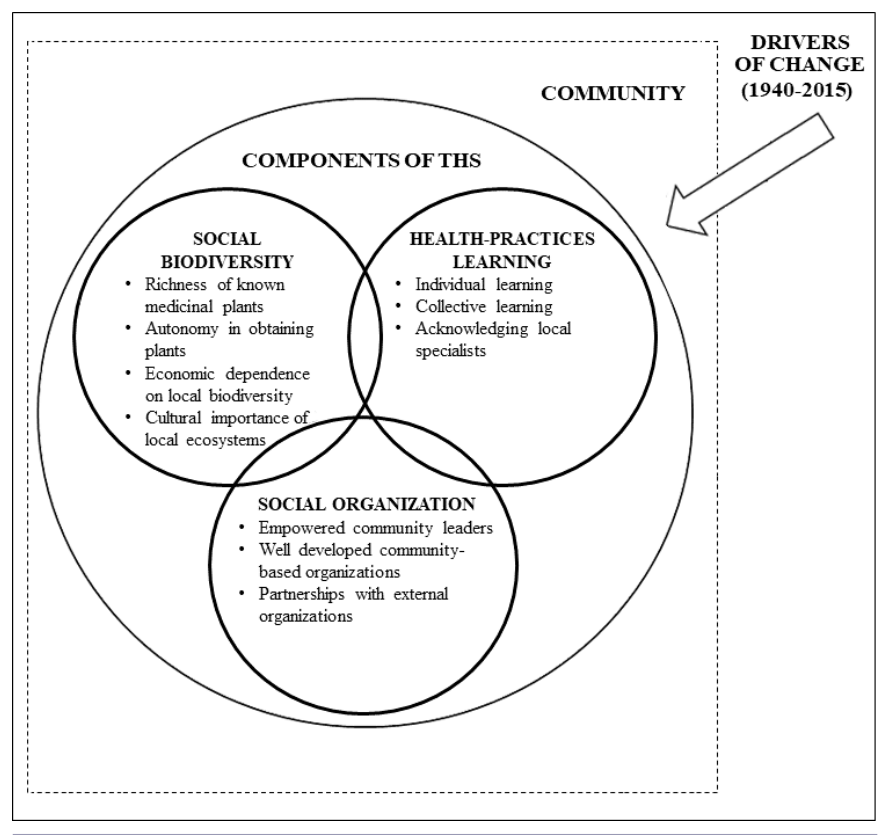

The participation of individuals from the studied communities was conditional on free and informed consent. The study was approved by the Research Ethics Committee at the Federal University of Santa Catarina, Chico Mendes Institute of Biodiversity (ICMBIO), and the National Institute of Historical and Artistic Heritage.

Based on the information collected through interviews, participatory workshops, and secondary data (published by both the authors themselves and by other researchers, see for example Ávila et al. 2015, Campos et al. 2015, Zank et al. 2015, 2016), we developed a narrative for (1) drivers of change acting on the THS and (2) the three components (social-biodiversity, health-practices learning, and social organization) contributing to adaptive capacity and resilience of the THS.

\section{DRIVERS OF CHANGE ACTING ON THE TRADITIONAL HEALTHCARE SYSTEMS (1940 TO 2015)}

Until the 1970s, people living in the two studied areas depended mainly on family agriculture and the extraction of natural resources. Part of the local production was regionally 
Fig. 3. Events affecting traditional healthcare systems (THS) and resulting changes in rural communities of Chapada do Araripe, northeastern Brazil. FHP = Family Health Program.

\begin{tabular}{|c|c|c|c|c|c|c|}
\hline \multicolumn{3}{|c|}{ Araripe Events } & \multirow[t]{2}{*}{ Time Line } & \multicolumn{3}{|c|}{ Araripe Changes } \\
\hline$\stackrel{\text { I }}{\text { Infrastructure }}$ & $\begin{array}{c}\text { II } \\
\text { Public Health } \\
\text { Policies }\end{array}$ & $\stackrel{\text { III }}{\text { Protected Areas }}$ & & $\stackrel{\text { I }}{\text { Infrastructure }}$ & $\begin{array}{c}\text { II } \\
\text { Public Health } \\
\text { Policies }\end{array}$ & $\stackrel{\text { III }}{\text { Protected Areas }}$ \\
\hline \multirow{4}{*}{$\begin{array}{l}\text { Better roads to access } \\
\text { urban centers; Electric } \\
\text { lights }\end{array}$} & & $\begin{array}{l}\text { Creation of Araripe } \\
\text { Forest }\end{array}$ & 1940 & \multirow[b]{2}{*}{$\begin{array}{l}\text { Start of selling products } \\
\text { from extracted plants }\end{array}$} & & \\
\hline & & & 1970 & & & \\
\hline & \multirow[t]{2}{*}{$\begin{array}{l}\text { Start of } \\
\text { vaccinations }\end{array}$} & & 1980 & $\begin{array}{l}\text { Search for work in the } \\
\text { city }\end{array}$ & & \\
\hline & & & & $\begin{array}{l}\text { Access to TV, } \\
\text { telephones, and home } \\
\text { appliances }\end{array}$ & & \\
\hline \multirow[t]{2}{*}{$\begin{array}{l}\text { Piped water in } \\
\text { Cacimbas }\end{array}$} & & $\begin{array}{l}\text { Implementation of } \\
\text { Araripe Forest and } \\
\text { land regularization }\end{array}$ & & Changes in diet & $\begin{array}{l}\text { Reduction in infant } \\
\text { mortality }\end{array}$ & $\begin{array}{l}\text { Extraction of medicinal } \\
\text { resources without } \\
\text { permission }\end{array}$ \\
\hline & & & 1990 & \multirow[t]{2}{*}{ New diseases } & \multirow{2}{*}{$\begin{array}{l}\text { Diagnosis of } \\
\text { diseases; } \\
\text { Use of industrialized } \\
\text { medicine }\end{array}$} & \\
\hline \multirow[t]{3}{*}{$\begin{array}{l}\text { Piped water and } \\
\text { cisterns in Maracujá }\end{array}$} & Initiation of FHP & & & & & \\
\hline & $\begin{array}{l}\text { Health center in } \\
\text { the }\end{array}$ & $\begin{array}{l}\text { Community } \\
\text { organization; }\end{array}$ & 2000 & & & \\
\hline & & $\begin{array}{l}\text { Creation of the } \\
\text { Araripe Forest } \\
\text { Consultative Council }\end{array}$ & & & & $\begin{array}{l}\text { Community } \\
\text { participation in the } \\
\text { Araripe Forest Council }\end{array}$ \\
\hline \multirow{2}{*}{ Internet service } & & & 2010 & \multirow{2}{*}{$\begin{array}{l}\text { Access to information } \\
\text { and influence of } \\
\text { globalization }\end{array}$} & & \\
\hline & & & & & & \\
\hline
\end{tabular}

commercialized as was the case of cassava, beans, corn, and sugarcane. Their livelihoods were deeply rooted in the natural resources of the local ecosystems. Treatment of health problems depended on local specialists and medicinal plants. The access to urban centers in search for healthcare treatment required long walks to locations with public transportation, or the use of animals; in rare situations people had cars.

The main drivers of change affecting the two THS were the (1) development of national and regional infrastructure; (2) development of national public health policies; (3) implementation of protected areas (PA); and (4) recognition of the Quilombola territory rights by the Brazilian State. The latter two refer to the implementation of Araripe Forest and the recognition of the Quilombola territories in southern Brazil (Fig. $3,4)$.

National and regional infrastructure (1970-2000)

Since the 1970s, the development of infrastructure in the country (construction and improvement of roads, piped and treated water, electric lights) has resulted in changes in lifestyles in the study areas. This shift gave communities access to mass communication (e.g., television and telephones), industrialized food and job opportunities in nearby urban areas, changing livelihoods, and increasing social network building within each region. The development of infrastructure primarily occurred in southern Brazil, and at the end of the 1970s in the region of Araripe. This process was very rapid in the south due to the proximity of large urban centers (São Paulo, Curitiba, and Porto Alegre).
Over the years, the search for salaried work gradually reduced the practice of agriculture and natural resources extraction. However, the communities still depended on extracting plant resources (ca. $70 \%$ of the population in Cacimbas, $60 \%$ in Maracujá, and $40 \%$ in Macaúba; Campos et al. 2015). In the Quilombola communities, there is a small percentage of adults generating income from agriculture (vegetables and fruits), breeding animals (cattle), and/or fishing (16\% in Fortunato, $2 \%$ in Santa Cruz, and $6 \%$ in Aldeia; Ávila et al. 2015). Along with hired jobs, activities related to tourism have been expanding since the end of the 1970s. This expansion has lead to an intense process of urbanization, resulting in more changes in lifestyle and ecosystems. As a consequence, in Morro do Fortunato and Santa Cruz, areas of native forest have increased as cultivated areas have diminished. On the other hand, urban occupation in the region of Aldeia has resulted in a decrease in native vegetation (Ávila et al. 2015).

Since the 2000s, internet services have brought more changes to both regions. With the use of electronic devices, communication and access to information have brought communities even closer to urban centers and the influence of globalization.

\section{Public health policies (decades 1970 to 2000)}

The construction of roads in the 1970s and the implementation of public transport services facilitated the access to hospitals in the cities. In Araripe, the first hospital was built in 1936 in the municipality of Crato (Hospital São Francisco de Assis 2015). In the south, hospitals were established in the city of Florianópolis since 1762 (Imperial Hospital de Caridade 2015) and in other 
Fig. 4. Events affecting traditional healthcare systems (THS) and resulting changes in Quilombola communities, southern coastal Brazil. FHP = Family Health Program.

\begin{tabular}{|c|c|c|c|c|c|c|}
\hline \multicolumn{3}{|c|}{ Quilombola Events } & \multirow[t]{2}{*}{ Time Line } & \multicolumn{3}{|c|}{ Quilombola Changes } \\
\hline $\begin{array}{c}\text { I } \\
\text { Infrastructure }\end{array}$ & $\begin{array}{c}\text { II } \\
\text { Public Health } \\
\text { Policies }\end{array}$ & $\begin{array}{c}\text { III } \\
\text { Quilombos }\end{array}$ & & $\begin{array}{c}\text { I } \\
\text { Infrastructure }\end{array}$ & $\begin{array}{c}\text { II } \\
\text { Public Health } \\
\text { Policies }\end{array}$ & $\begin{array}{c}\text { III } \\
\text { Quilombos }\end{array}$ \\
\hline $\begin{array}{l}\text { Access to electric } \\
\text { lights; Better roads; } \\
\text { Mass tourism }\end{array}$ & $\begin{array}{l}\text { Health center in } \\
\text { the municipalities }\end{array}$ & & 1970 & & & \\
\hline \multirow[t]{4}{*}{ Urbanization } & & & 1980 & Access to hospitals & $\begin{array}{l}\text { Reduction in infant } \\
\text { mortality }\end{array}$ & \\
\hline & & & & $\begin{array}{l}\text { Access to TV, } \\
\text { telephones, and } \\
\text { home appliances; } \\
\text { Search for work in the } \\
\text { city }\end{array}$ & $\begin{array}{l}\text { Diagnosis of illnesses } \\
\text { Use of industrialized } \\
\text { medicine }\end{array}$ & \\
\hline & & & 1990 & $\begin{array}{l}\text { Changes in diet; } \\
\text { New diseases }\end{array}$ & & \\
\hline & $\begin{array}{l}\text { Initiation of the } \\
\text { FHP }\end{array}$ & & & & & \\
\hline \multirow[t]{4}{*}{$\begin{array}{l}\text { Growth in mass } \\
\text { tourism }\end{array}$} & & & 2000 & & & \\
\hline & & $\begin{array}{l}\text { Recognition of the } \\
\text { Quilombos }\end{array}$ & & Internet access & & \\
\hline & & & 2010 & & & \multirow{2}{*}{$\begin{array}{l}\text { Strengthening of } \\
\text { identity; } \\
\text { Access to public } \\
\text { housing and food } \\
\text { policies; } \\
\text { Valorization of } \\
\text { traditional knowledge } \\
\text { and practices }\end{array}$} \\
\hline & & & & & & \\
\hline
\end{tabular}

municipalities even closer to the communities since 1856 (Hospital de Laguna 2015). Improved access to urban centers made it possible for the communities in the northeast and southern regions to make greater use of biomedical resources.

The federal government's Family Health Program (FHP) is an important public policy introduced in 1990. It provides easy access to biomedicine in the isolated communities through the establishment of health centers and community healthcare agents. The agents are locals, trained by the National Health Foundation to promote health prevention actions and aid people in accessing healthcare services.

In Araripe, the FHP had a huge impact on the communities' health systems. First with the arrival of healthcare agents in the 1990s and then with the building of health centers in the 2000s. Presently, FHP provides weekly medical care in Macaúba and Cacimbas; in Maracujá, residents drive to a neighboring locality to have access to a health center. In these three communities, there is home medical care for the elderly and people with limited mobility. The FHP is very significant mostly because it reduced infant mortality in the region.

In the Quilombola communities, healthcare agents started to arrive at the end of the 1990s; however, there were health centers since the 1970s in nearby urban centers. Morro do Fortunato has medical care in the community once per month.

Access to government health programs (healthcare agents, health centers, vaccination campaigns, home doctors) and improved basic conditions (e.g., clean water) have led to a reduction in some sicknesses in the communities, mainly those affecting children (e. g., viruses and dehydration). In the two regions, residents reported new illnesses due to lifestyle changes, especially those related to health and biomedical advances in diagnosis. Cancer, high blood pressure, diabetes mellitus, high cholesterol, strokes, and depression were cited as recent sicknesses in the two regions. Osteoporosis and dengue were cited only in Araripe, whereas spinal pain and AIDS were cited only in Quilombola communities. Diseases that have become more common in the last decades are mainly treated with biomedicine, although some healers pray and use plants to treat them. Easy access to biomedical resources allows the simultaneous and complementary use of biomedicine and traditional practices (Zank and Hanazaki 2017).

\section{Implementation of the Araripe Forest (1980s)}

The National Forest of Araripe (or Araripe Forest) is a protected area (PA) created in 1946 but only implemented in 1983. Until the 1980s, the Araripe communities used areas within this PA for agriculture and the extraction of plant resources (e.g., pequi, Caryocar brasiliense; janaguba, Himatanthus drasticus; and mangaba, Hancornia speciosa). After 1983, the communities were forced to move their cultivated areas outside the limits of Araripe Forest. Access to medicinal plants within the PA was prohibited from this date, including for family use. The management plan of Araripe Forest, which guides its management strategies and actions, allows for sustainable harvesting of only four species (faveira, Dimorphandra gardneriana; pequi, Caryocar coriaceum; mangabeira, $H$. speciosa; and janaguba, $H$. drasticus) and the collection of dry wood for domestic use by families with low income. 
Table 2. Elements of adaptive capacity and resilience based on traditional health services (THS) components (social biodiversity, learning, and social organization) in the Araripe and Quilombola communities. MA = Macaúba, CA = Cacimbas, MR = Maracujá, $\mathrm{MF}=$ Morro do Fortunato, $\mathrm{ST}=$ Santa Cruz, AL $=$ Aldeia.

\begin{tabular}{|c|c|c|c|c|c|c|c|}
\hline \multirow{2}{*}{$\begin{array}{l}\text { Resilience and } \\
\text { Adaptability } \\
\text { Elements }\end{array}$} & \multirow[t]{2}{*}{ Description } & \multicolumn{3}{|c|}{ Chapada do Araripe } & \multicolumn{3}{|c|}{ Quilombolas } \\
\hline & & MA & $\mathrm{CA}$ & MR & MF & ST & $\overline{A L}$ \\
\hline $\begin{array}{l}\text { Social biodiversity } \\
\text { Medicinal plant } \\
\text { richness }\end{array}$ & $\begin{array}{l}\text { Medicinal plants known by local health } \\
\text { specialists. The greater the richness of knowledge, } \\
\text { the greater the diversity of healing strategies } \\
\text { during conditions of change. }\end{array}$ & High & High & Medium & Medium & Medium & High \\
\hline $\begin{array}{l}\text { Autonomy to obtain } \\
\text { medicinal plants }\end{array}$ & $\begin{array}{l}\text { Obtaining medicinal plants through cultivation } \\
\text { and extraction. The more equal the use of } \\
\text { cultivated and extracted plants, the greater the } \\
\text { autonomy of the community in obtaining these } \\
\text { resources to treat illnesses. }\end{array}$ & High & High & High & Medium & Medium & Medium \\
\hline $\begin{array}{l}\text { Economic } \\
\text { dependence on } \\
\text { biodiversity }\end{array}$ & $\begin{array}{l}\text { Natural resources are a source of income for the } \\
\text { community. }\end{array}$ & High & High & High & Medium & Low & Low \\
\hline $\begin{array}{l}\text { Cultural importance } \\
\text { of biodiversity }\end{array}$ & $\begin{array}{l}\text { Natural resources are a source of cultural values, } \\
\text { healthcare practices, and ecosystem services. }\end{array}$ & High & High & High & Medium & Medium & Medium \\
\hline \multicolumn{8}{|c|}{ Health-practices learning } \\
\hline Individual learning & $\begin{array}{l}\text { The predominance of family transmission } \\
\text { (vertical), with innovation events (horizontal, } \\
\text { oblique, other), allows traditional knowledge to } \\
\text { be maintained over generations. }\end{array}$ & High & High & High & High & High & High \\
\hline $\begin{array}{l}\text { Valorization of } \\
\text { specialist }\end{array}$ & $\begin{array}{l}\text { Demand for local health specialists to help in the } \\
\text { curing process. The valorization of specialists } \\
\text { favors the continuity of traditional practices. }\end{array}$ & Present & Present & Present & $\begin{array}{l}\text { Partially } \\
\text { present }\end{array}$ & $\begin{array}{c}\text { Partially } \\
\text { present }\end{array}$ & $\begin{array}{c}\text { Partially } \\
\text { present }\end{array}$ \\
\hline Collective learning & $\begin{array}{l}\text { Spaces of reflection, discussion and conversation } \\
\text { about health and management of natural } \\
\text { resources. }\end{array}$ & Present & Present & Present & Present & Absent & Present \\
\hline \multicolumn{8}{|l|}{ Local organization } \\
\hline Local leaders & $\begin{array}{l}\text { Individuals with skills to organize collective } \\
\text { actions. }\end{array}$ & Present & Present & Present & Present & $\begin{array}{l}\text { Partially } \\
\text { present }\end{array}$ & Present \\
\hline CBOs & $\begin{array}{l}\text { Number of community-based organizations } \\
\text { (CBOs). }\end{array}$ & High & Medium & High & High & Low & Medium \\
\hline $\begin{array}{l}\text { External } \\
\text { partnerships }\end{array}$ & $\begin{array}{l}\text { Number of links of local organizations with } \\
\text { outside organizations. }\end{array}$ & Medium & Medium & High & High & Medium & Medium \\
\hline
\end{tabular}

In 2004, the Consultative Council of Araripe Forest was established, and the community of Macaúba has accepted a chair in the council. Members of the communities have asked for licensing and regulation for plant extraction within the PA, indicating the response of the communities to this recently implemented institutional arrangement.

\section{Recognition of Quilombola territories (2000s)}

Although guaranteed in the Federal Constitution of 1988, the Afro-descendant populations have been requesting property rights of their territories for decades. Morro do Fortunato was recognized as a Quilombo in 2006, Santa Cruz in 2007, and Aldeia in 2010 (Fundação Cultural Palmares 2014). Although recognized, these territories have not been legally regulated by law until now.

The people of Morro do Fortunato reported that the cultural value of their agriculture has been making a comeback since the community was recognized as a Quilombola community. This comeback in agriculture is perceived based on the sale of crops and processed products, such as sweets, cookies, and cakes. Another benefit gained by the population was the access to public subsidies to obtain housing. In Aldeia, after being recognized as a Quilombo, the community was given access to basic food items and housing subsidies through government programs. In this community, local leaders sought to enrich the cultivation of food products and medicinal plants for community use. In Santa Cruz, access to basic foodstuffs was the only benefit provided after the community was recognized as a Quilombo.

\section{COMPONENTS CONTRIBUTING TO ADAPTIVE CAPACITY AND RESILIENCE OF THE THS}

Currently, the THS are characterized by practices and knowledge of both traditional medicine and biomedicine. Over the decades, social, economic, and environmental changes affected the socialbiodiversity components (focusing on plant diversity for 
medicinal use), health-practices learning, and social organization of the THS. In response to the effect of several drivers of change, those components have been changing and THS adapting in a continuous process that enhances or dampens resilience of the THS.

\section{Social biodiversity focusing on plant diversity for medicinal use}

The richness of known plants by the specialists in the THS is a core strength to sustain resilience and adaptive capacity. More known plants means diversification of strategies for different treatments. Macaúba (Araripe), Cacimbas (Araripe), and Aldeia (Quilombola) were notable for 153, 132, and 128 known species, respectively (Table 2). These three communities stand out from others in relation to the diversity of known plants (Zank et al. 2015, 2016).

Regarding the autonomy in obtaining medicinal plants, in Araripe there is a greater autonomy represented by the balance between plants extracted and cultivated (close to 50\%), compared to the Quilombola communities in which there is a preponderance of cultivated plants (Table 2). Purchasing plants in local markets is a common occurrence in the studied communities, especially in the Quilombola communities (Ávila et al. 2015), making the THS more vulnerable because it depends on markets.

Natural resources generate a source of income and cultural value in Araripe and Quilombola communities. The economic dependence and cultural importance given to biodiversity is higher in the Araripe communities (Table 2), where people depend more on the extraction and cultivation of plants for household consumption and commercialization (Baldauf and Santos 2013, Feitosa et al. 2014, Silva et al. 2015), in the way that the communities' way of life is closely related to local ecosystems. In contrast, in the southern communities, only Morro do Fortunato is economically dependent on plant species (Ávila et al. 2015), although biodiversity is culturally important in all communities. After the recognition of their territories, maintaining and enriching traditional knowledge and practices became an increasing concern (e.g., cultivating medicinal and food plants). These results show that even with modernization, communities strengthen their cultural identity through their interaction with local ecosystems, mainly through initiatives of plant extraction and cultivation.

\section{Health-practices learning}

In relation to individual learning, we realize that in all communities vertical knowledge transmission is predominant for medicinal plants (Fig. 5; Table 2), in addition to some people having learned by more than one way.

Collective learning was observed in arenas in which learning, reflecting, and decision making on health and management of natural resources took place (Table 2). In Araripe, in addition to CBOs, schools, churches, elderly groups, and the Consultative Council of Araripe Forest were all considered as collective learning arenas. In the Quilombola communities, the CBOs of Morro do Fortunato and Aldeia were places in which the elderly, mothers, and women congregated. These groups meet for lectures and talks about human and environmental health. In Santa Cruz, there is no collective spaces for meetings.
Fig. 5. Learning about medicinal plants in Araripe communities (Macaúba $\mathrm{n}=22$ interviews, Cacimbas $\mathrm{n}=15$ interviews, Maracujá $n=15$ interviews) and Quilombola communities (Morro do Fortunato $n=63$ interviews, Santa Cruz $n=56$ interviews, Aldeia $n=65$ interviews).
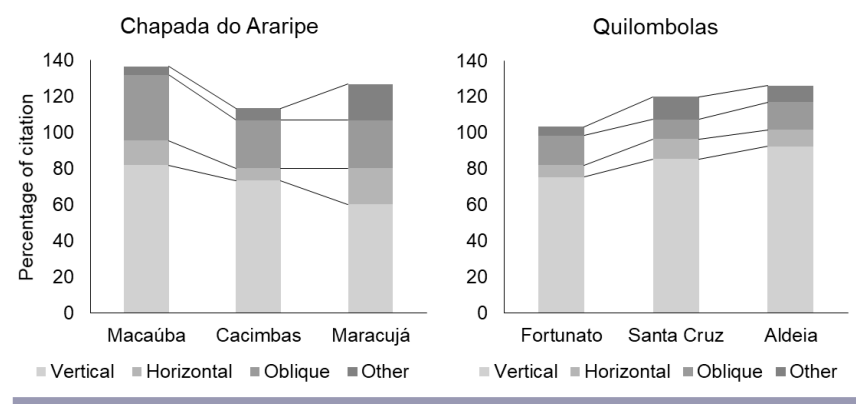

Valuing local healers is still a practice in the communities of Araripe, however in the Quilombola communities this has diminished. In a previous study, it has been recorded that $75 \%$ of local healers of the Quilombola communities are in lesser demand by the community, in contrast to the Araripe communities, where this same decrease is perceived by about $20 \%$ of the healers (Zank and Hanazaki 2017; Table 2). The perception of healers' devaluation can discourage younger people from following this activity, and thus influence knowledge transmission and the continuity of such practices.

\section{Social organization}

In the studied communities, local leaders with skills to organize collective action are legitimized by the community. The exception to this is the community of Santa Cruz, which has difficulty in accepting local leaders because of conflicts among families (Table 2).

The CBOs act at the community level, collaborating to increase the empowerment and autonomy of community members on issues related to professional qualifications, income generation, struggling for rights, among others. The communities of Macaúba, Maracujá, and Morro do Fortunato have several CBOs working in partnership with governmental and nongovernmental organizations at the municipal, state, and federal levels. Cacimbas, Aldeia, and Santa Cruz have fewer CBOs. Despite this, some of them stand out for their power to act on behalf of the community's interests, rights, and needs. This is the case of the CBOs in Aldeia and Santa Cruz, representing the interests of the communities at the Unified National Black Movement (Movimento Negro Unificado). In the case of Cacimbas, despite the small number of CBOs, one of them works in partnership with several external organizations (Fig. 6, 7; Table 2).

In Araripe, some CBOs receive technical and financial support from external organizations. They also have other sources of income from product sales, which indirectly reinforce their demand for rights. This is the case for requesting permits to use plant resources collected inside the Araripe Forest. In Quilombola communities, CBOs consolidate common interests of their members and publicize information about the access to government benefits, financial return from selling local products, and the struggle for Quilombola rights to their lands. In this way, 
Fig. 6. Social networks of the rural communities in Araripe, northeastern Brazil. Organizations within the dotted circle are community-based organizations (CBOs) and those outside the circle are partners in levels above the community. The arrows indicate partnership between organizations.
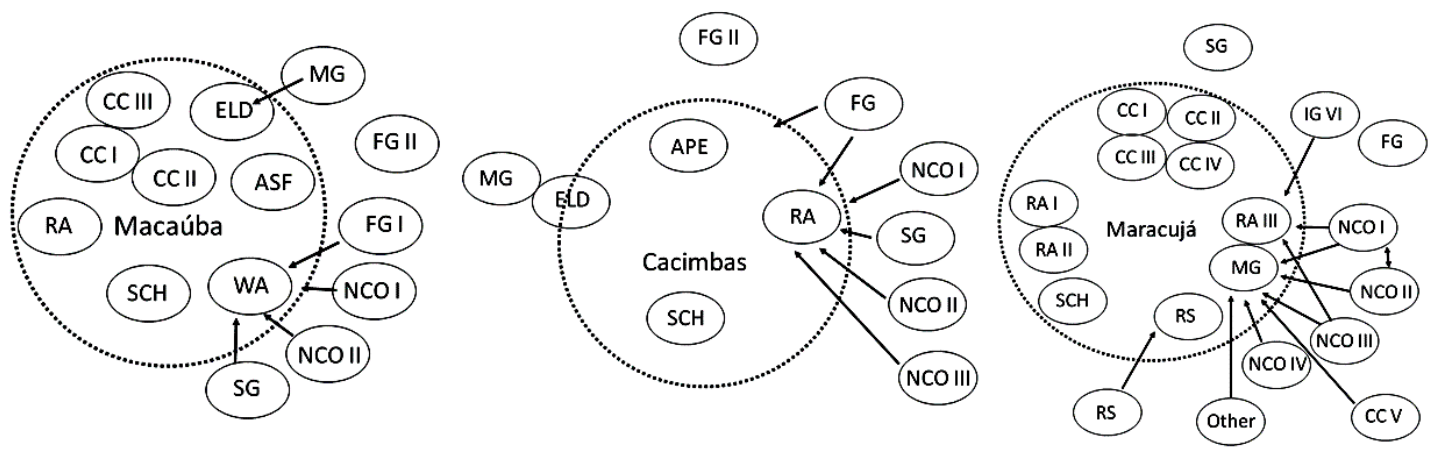

Community-based organizations (CBOs):

RA = Resident Associations

WA $=$ Women's Association

ASF = Association of Small Farmers

APE $=$ Association of Pequi Extractors

$\mathrm{CC}=$ Groups linked to the Catholic Church

$\mathrm{SCH}=$ School

ELD = Elderly Group
Outside Institutions:

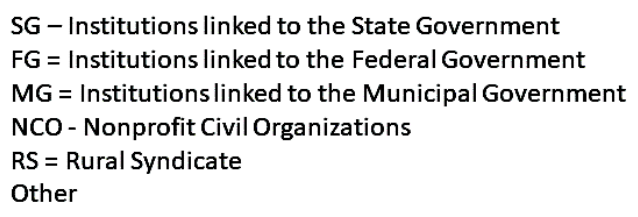

SG - Institutions linked to the State Government FG = Institutions linked to the Federal Government MG = Institutions linked to the Municipal Government NCO - Nonprofit Civil Organizations RS = Rural Syndicate Other

social organization contributes to the process of empowerment of the communities concerning the management of natural resources and cultural identity.

Comparing the different responses of components that contribute to the resilience and adaptive capacity of the THS, it is evident that Macaúba and Maracujá communities, in Araripe, possess a greater ability to respond to crises and changes than Cacimbas (Table 2). Strengthening community organization and forming more partnerships in Cacimbas could make this community less vulnerable to crises.

In the Quilombola communities, components affecting adaptive capacity and resilience of THS varied more among the communities compared to Araripe. Morro do Fortunato is richer in social biodiversity, learning, and social organization, and should be a learning guide for the other communities. In general, among the Quilombola communities, acknowledging local health specialists (such as healers), valuing knowledge about medicinal plants (mainly wild species), improving income from land use, and strengthening CBOs and partnerships (e.g., with universities and NGOs) would make resilience of THS increase. Santa Cruz is in a more vulnerable situation compared to the other communities because it lacks local leadership, empowered CBOs, network building, and a physical space that could stimulate collective action.

\section{DISCUSSION}

Within the contexts studied, we considered that resilient THS are characterized by communities with high social biodiversity, active and continuous learning processes, and strong social organization. The development of healthcare infrastructure and public policies in the country promoted changes in the communities studied and, consequently, in their THS. In both regions, but more intensely in the communities of the south, these changes are related to the access to jobs in the cities and to biomedicine in both nearby cities and within communities, including health centers and healthcare agents. In the northeastern communities, the establishment of the Araripe Forest triggered changes in the access and use of plant resources, affecting the local economy and THS. In the south, the recognition of Quilombola territories triggered a process of revitalization of local culture and resumption of old lifestyle habits, including the recovery of traditional medicine elements. These changes have led people to incorporate new elements and processes into the THS, and therefore are adapting to new lifestyle conditions.

Changes resulting from access to modern medical benefits and more contact with urban life contributed to enhance community resilience and THS vulnerabilities simultaneously. The improvement in diagnosis and treatment of sicknesses, the expansion of infant vaccination, and the construction of cisterns (in Araripe) may have contributed to decreased infant mortality and broadly enhanced well-being in all the studied communities. Although this is a significant aspect of community resilience strengthening, at the same time, it represents a dimension of vulnerability of the THS, among other factors, because traditional healthcare practices (e.g., demand for healers) and traditional knowledge (e.g., decrease in the use of native species) may have lost importance. This situation varied a lot among the communities. In Araripe, dependence on plant resources, valorization of local specialists, and the continuity of learning processes have together protected THS from these vulnerabilities 
Fig. 7. Social networks of the Quilombola communities, on the southern coast of Brazil. Organizations within the dotted circle are community-based organizations (CBOs) and those outside the circle are partners in levels above the community. The arrows indicate partnership between organizations.

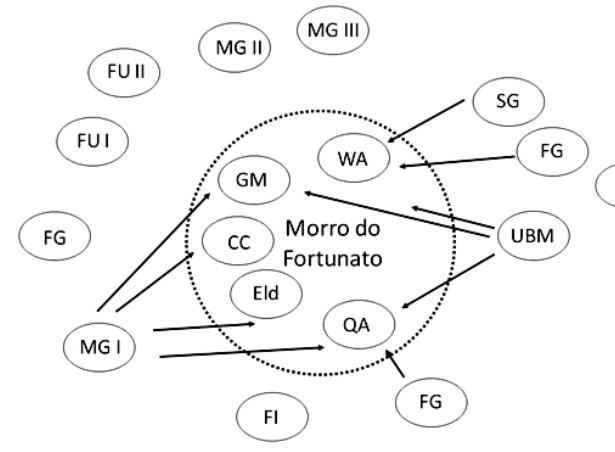

Community-based Organizations (CBOs):

$$
\begin{aligned}
& \text { QA = Quilombola Associations } \\
& \text { WA = Women's Association } \\
& \text { GM = Group of Mothers } \\
& \text { CC - Groups linked to the Catholic Church } \\
& \text { Eld = Elderly Group } \\
& \text { Soc = Soccer Association }
\end{aligned}
$$
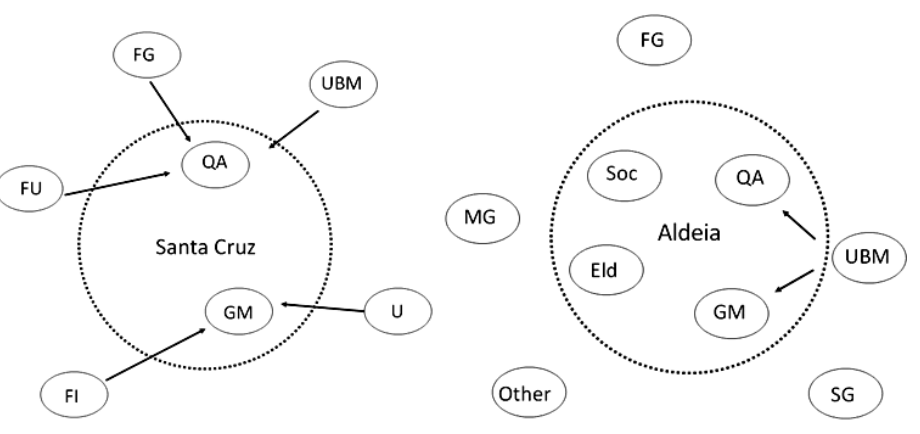

Outside Institutions:

$\mathrm{FG}=$ Institutions linked to the Federal Government SG = Institutions linked to the State Government MG = Institutions linked to the Municipal Government $\mathrm{UBM}=$ Unified Black Movement

$\mathrm{U}=$ University

$\mathrm{FU}=$ Federal University

$\mathrm{FI}=$ Federal Institute

Other and strengthened resilience at the community level. In the southern communities, the elements that have weakened THS are more influential, such as lack of appreciation for local specialists, increased contact with urban centers, and less dependence on local biodiversity.

In general, communities have not stopped using traditional healing knowledge and practices, but they use them in a complementary way with biomedicine (Zank and Hanazaki 2017). Knowledge and practices related to THS are preferred and accessed to treat mild health problems that do not require biomedical care, such as gastrointestinal problems, general pain, flues, and colds. The biomedicine is principally used for problems related to blood pressure, general pains, and endocrine and nutritional problems (Zank and Hanazaki 2017). In addition, THS also incorporate cultural and spiritual diseases, such as evil eye, which are part of the health cosmovision of these traditional communities (Zank and Hanazaki 2016) and not treated by biomedicine.

The current conditions of medicinal plant diversity, learning processes, and social organization in each community indicate which components of the related THS strengthen adaptive capacity and resilience of these systems and which components induce vulnerabilities. It is possible, therefore, to point out aspects that should be nurtured to increase the resilience of THS.

Urbanization effects on the Quilombola THS have undermined the resilience of these systems. These effects were observed through the impoverishment of social-biodiversity elements such as knowledge about plants, autonomy for obtaining plants, economic dependence on local biodiversity, and cultural importance given to local ecosystems. The gradual modification of the rural environment to urbanized ones ends up weakening and even rendering unfeasible traditional practices; the communities no longer have available environments where native plants spontaneously grow or are suitable for plant cultivation. In addition, urbanization provides greater accessibility to jobs outside the community, which increases income on the one hand, but also decreases the time devoted to cultural practices that maintains the identity of these groups. In the Quilombola communities, continuous changes in lifestyle have modified structural components of their THS. Of the three communities, Aldeia has a higher diversity of plant knowledge that can be a source of resilience to their THS and also to other communities through the exchange of knowledge. Santa Cruz THS is more vulnerable compared to the two other Quilombola communities. It has less social-biodiversity elements capable of reinforcing the resilience and adaptive capacity of its THS, including a reduced dependence on local biodiversity. However, it still maintains aspects of cultural valorization in relation to local ecological knowledge. Eyssartier et al. (2013) argued that cultivation and extraction of plants contribute to the resilience of knowledge and the ecosystem by promoting flexibility and autonomy of the communities to access plants and conserve germplasm. In this context, the community of Santa Cruz can draw on the cultural importance it still maintains for local biodiversity and exchange this with the other two communities, which would enrich elements of learning and appreciation of the local specialists.

Learning about medicinal plants and other traditional healthcare practices through living and sharing of daily activities with the family and community is a powerful strategy of "learning by doing" (Lozada et al. 2006). The predominance of vertical transmission, which is the most conservative, combined with other forms of transmission that guarantee innovation, allow for the perpetuation and adaptation of this knowledge, helping 
communities to deal with changes that influence health and wellbeing. In addition, it is also vital that local specialists continue to be valued and recognized. They are imbued with the challenge of encouraging young people to take interest in traditional healing practices and the transmission of traditional knowledge associated with health. In the communities studied, individual and collective learning processes are alive and are based on cooperation, favoring adaptive responses to the current changes in the THS. Cooperation is fundamental for the adaptation and evolution of every human society (Boyd and Richerson 2009, Boyd et al. 2011). It is still necessary to invest in collective spaces and actions to maintain the evolution of learning processes, mainly in the community of Santa Cruz where there are no collective action spaces. At both sites it is also important to ensure access to natural ecosystems that allow not only the transmission of knowledge but also innovation and the production of new knowledge.

Strengthening community-based organizations and partnerships with external organizations that collaborate in health and development issues is a potential characteristic to enhance THS resilience because these social networks help build social capital in the communities. Different capacities among people living in communities are favored by social capital, such as collective actions and self-organizing to deal with external pressures (Berkes and Ross 2013, Nguyen and James 2013, Prado et al. 2015). Confidence, reciprocity, positive leadership, and sharing local knowledge are required ingredients when developing collective actions (Basurto et al. 2013). In the same context, Gutiérres et al. (2011), in an evaluation of comanagement regimes associated with fishing, identified that the presence of strong leaders is the most important attribute that leads to the success of the regimes. The representation of community interests in the Consultative Council of Araripe Forest by empowered leaders and CBOs is evidence of the importance of building social capital at the community level. These leaders and CBOs are gaining power and abilities to negotiate their needs regarding extraction and sustainable management of medicinal plants collected within the Araripe Forest. In the end, these efforts can be translated into elements capable of enhancing THS resilience.

In the Quilombola communities, the resilience of THS and the process of recognizing the Quilombola territories are related and linked by the challenge of rescuing cultural identity. The idea of cultural resilience can be applied to this case because it places the identity of a community or people at the center of nurturing resilience. Cultural resilience is defined as "the capacity of a distinct community or cultural system to absorb disturbance and reorganize while undergoing change so as to retain key elements of structure and identity that preserve its distinctness" (Healy 2006:12). The appreciation of world views, spirituality, and traditional knowledge about health are fundamental elements to the identity and cultural resilience of the Quilombola communities. For these communities, a path to strengthen THS resilience is to create actions that rescue and enrich their Afrodescendant identity and related knowledge. In the communities of Aldeia and Santa Cruz, where the natural environment is extremely modified and there is no economic dependence on local biodiversity, strengthening THS resilience could be done through cultural appreciation, collective-learning processes, and especially through community empowerment. In the 1980 s, empowerment began to be seen as a strategy of social transformation, seeking to empower groups to define, and collectively, claim their rights (Lutrell et al. 2007). A strong influence on this topic came from Paulo Freire's work, such as the "pedagogy of the oppressed" and "education as a practice of freedom" (Freire 1986, 1988). Empowerment can be defined as a process that helps individuals or groups of individuals gain control over their own lives by increasing their ability to work on issues that they themselves define as important (Eyben et al. 2008). In the context of traditional practices associated with biodiversity, diverse community empowerment initiatives are developed as a way to contribute to the resilience and adaptability of communities, such as the Pancur Empowerment Movement in Indonesia (Tamayo et al. 2012) and the initiatives of Community Biodiversity Management applied in several countries such as Nepal, India, Ethiopia, and Brazil (de Boef et al. 2013).

Thorkildsen (2014) analyzed social-ecological changes in a Quilombola community in southeastern Brazil and noted that obtaining the title to land is essential to build resilience of traditional agricultural practices. In the Quilombola communities of this study, the regulation of their territory could be beneficial to the acknowledgement of traditional health practices (e.g., guaranteed access to environments in which wild medicinal plant species occur), which would indirectly favor THS resilience. In addition, the titling and regularization of the territory allow collective ownership by the community, which stimulates social organization for the management of this space and the cultural practices that are maintained through them, such as THS.

An important argument is that resilient THS contribute to the health and resilience of the communities attached to them. Strengthening adaptive capacity and resilience of desirable THS depends on internal and external factors to the communities. Among them are partnerships and interactions with groups and organizations outside the community as components of social capital. Resilience of community systems (livelihood resilience), as found among the Caiçaras in southeastern Brazil, results from forces at the community level combined with the effects of development and environmental conservation drivers (Prado et al. 2015). To a certain extent, the same process takes place in the region of Araripe regarding the development and implementation of protected areas, and in the Quilombola communities with the evolution of urbanization, tourism, and the consolidation of Quilombo territories. Building resilience and capacity to adapt at the community level requires emergent characteristics at higher levels capable of influencing THS positively. For example, the recognition of the territory of the Quilombola communities depends on negotiations with government agencies at the federal level. In Araripe, the permits for extraction of other wild species depend on ecological studies and on the regulation of this activity by the Federal Protected Areas Agency. All these measures, which take place on more than one level above communities, are fundamental to enhancing adaptability and resilience at the local level, both for the community and for their respective THS.

We recognize that this study has limitations. Although it aims to analyze the resilience of THS using several attributes, some relevant issues could not be deepened, such as governance analysis, or ecological redundancy of plants used. In addition, this study did not aim to verify causal effects on resilience, but 
more broadly sought to understand how resilience of THS influences community resilience and vice-versa. Considering that our analysis reflects the complexity and specificity of the historical, cultural, and environmental contexts of these Brazilian regions, the results cannot be widely generalized. On the other hand, the framework presented can be reapplied in other contexts to broaden the discussions about the resilience of different THS.

Resilience thinking can unite common healthcare and environmental conservation interests among communities and government agencies. In both Araripe and Quilombola communities, THS possess numerous elements of resilience and innovation that could contribute to environmental conservation, such as knowledge about native plants. The evolution of the studied THS is challenged by the capacity of the communities to value, innovate, and transmit local knowledge on the daily use of medicinal species, as well as to strengthen individuals to better integrate the communities and external partners that directly affect the THS. In addition, the data from this study serve as a substrate for stakeholders that act as partners in these communities, such as public agents, NGOs, and researchers, so that actions can contribute to enhance resilience of THS.

\section{CONCLUSIONS}

The main drivers influencing the THS in the two studied areas were modernization and improved access to biomedicine with the most significant changes occurring from the 1970s to the 2000s. The region of Araripe was also influenced by the implementation of the Araripe Forest, in the 1980s, limiting access to some medicinal resources. In the Quilombola communities, the recognition of the Quilombola territories in the 2000s led to changes in access to government benefits and the valorization of local culture. The communities have responded to these drivers through the simultaneous use of traditional medicine and biomedical resources, and by organizing themselves locally to seek social, environmental, and economic benefits, including healthcare.

The most critical element threatening the resilience of the studied THS relates to social organization. Strengthening local leadership, CBOs capable of revitalizing knowledge and representing communities' interests, and networks with external partners could develop social capital in the communities. In turn, more social capital could strengthen resilience and adaptability in both THS and communities through a positive feedback between both systems.

Responses to this article can be read online at: http://www.ecologyandsociety.org/issues/responses. php/10701

\section{Acknowledgments:}

We thank Macaúba, Cacimbas, Maracujá, Morro do Fortunato, Santa Cruz, and Aldeia communities for making this study possible. We also thank: U. P. Albuquerque and the Laboratorio de Etnobiologia Aplicada e Teórica for the fieldwork support in Araripe; M. L. Mina (Movimento Negro Unificado de Santa
Catarina) for help with initial contacts with Quilombola communities; Gaia Village, J. V. Ávila, K. O. Valadares, J. Maragno, D. F. Herbst, R. Dalbem, M. C. Ribeiro, M. L. Leal, D. G. Martins, G. R. Mirizolla, G. Pasqualetti, M. E. Beretta, G. L. Antunes, M. C. Baumann, J. Copetti, and A. R. Gimenez for support during fieldwork in Quilombola communities, and $J$. V. Ávila for assistance in data collection in Araripe; A. A. Mendonça, M. Ritter, A. Mello, and $P$. C. Simionato for helping in plants identification; and $C N P q$ for the Productively Research Grant awarded to N. Hanazaki (309613/2015-9) and CAPES for PhD fellowship awarded to $S$. Zank. This study was financed in part by the Coordenação de Aperfeiçoamento de Pessoal de Nível Superior - Brasil (CAPES) - Finance Code 001.

\section{LITERATURE CITED}

Ávila, J. V. C., S. Zank, K. O. Valadares, J. M. Maragno, and N. Hanazaki. 2015. The traditional knowledge of Quilombola about plants: does urbanization matter? Ethnobotany Research and Applications 14:453-462. http://dx.doi.org/10.17348/era.14.0.453-462

Armitage, D., A. Charles, and F. Berkes. 2017a. Governing the coastal commons: communities, resilience and transformation. Routledge, New York, New York, USA. http://dx.doi. org/10.4324/9781315688480

Armitage, D., A. Charles, and F. Berkes. 2017b. Towards transformative change in the coastal commons. Pages 1-21 in D. Armitage, A. Charles, and F. Berkes, editors. Governing the coastal commons: communities, resilience and transformation. Routledge, New York, New York, USA. http://dx.doi.org/10.4324/9781315688480-1

Armitage, D., M. Marschke, and R. Plummer. 2008. Adaptive comanagement and the paradox of learning. Global Environmental Change 18:86-98. http://dx.doi.org/10.1016/j.gloenvcha.2007.07.002

Baldauf, C., and F. A. M. Santos. 2013. Ethnobotany, traditional knowledge, and diachronic changes in non-timber forest products management: a case study of Himatanthus drasticus (Apocynaceae) in the Brazilian Savanna. Economic Botany 67 (2):110-120. http://dx.doi.org/10.1007/s12231-013-9228-5

Basurto, X., S. Gelcich, and E. Ostrom. 2013. The socialecological system framework as a knowledge classificatory system for benthic small-scale fisheries. Global Environmental Change 23 (6):1366-1380. http://dx.doi.org/10.1016/j.gloenvcha.2013.08.001

Berkes, F. 1999. Sacred ecology: traditional ecological knowledge and resource management. Taylor and Francis, Ann Arbour, Michigan, USA.

Berkes, F. 2005. Conexões institucionais transescalares. Pages 293-332 in P. F. Vieira, F. Berkes, and C. S. Seixas, editors. Gestão integrada e participativa de recursos naturais - conceitos, métodos e experiências. Secco/APED, São Paulo, Brazil.

Berkes, F., J. Colding, and C. Folke. 2003. Navigating socialecological systems: building resilience for complexity and change. Cambridge University Press, Cambridge, UK. http://dx.doi. org/10.1017/CBO9780511541957

Berkes, F., and D. Jolly. 2001. Adapting to climate change: socialecological resilience in a Canadian western Arctic community. Conservation Ecology 5(2):18. http://dx.doi.org/10.5751/ES-00342-050218 
Berkes, F., and H. Ross. 2013. Community resilience: toward an integrated approach. Society and Natural Resources: An International Journal 26(1):5-20. http://dx.doi.org/10.1080/08941920.2012 .736605

Berkes, F., and N. J. Turner. 2006. Knowledge, learning and the evolution of conservation practice for social-ecological systems resilience. Human Ecology 34:479-494. http://dx.doi.org/10.1007/ s10745-006-9008-2

Boyd, R., and P. J. Richerson. 2009. Culture and the evolution of human cooperation. Philosophical Transactions of the Royal Society B 364:3281-3288. http://dx.doi.org/10.1098/rstb.2009.0134

Boyd, R., P. J. Richerson, and J. Henrich. 2011. The cultural niche: why social learning is essential for human adaptation. Proceedings of the National Academy of Sciences 108(2):10918-10925. http:// dx.doi.org/10.1073/pnas. 1100290108

Campos, L. Z. O, U. P. Albuquerque, N. Peroni, and E. L. Araújo. 2015. Do socioeconomic characteristics explain the knowledge and use of native food plants in semiarid environments in Northeastern Brazil? Journal of Arid Environments 115:53-61. http://dx.doi.org/10.1016/j.jaridenv.2015.01.002

Cavalli-Sforza, L. L., M. W. Feldman, K. H. Chen, and S. M. Dornbusch. 1982. Theory and observation in cultural transmission. Science 218(4567):19-27. http://dx.doi.org/10.1126/ $\underline{\text { science. } 7123211}$

Convention on Biological Diversity (CBD). 2010. Updated global strategy for plant conservation 2011-2020. Secretariat of the Convention on Biological Diversity, Montreal, Quebec, Canada. [online] URL: https://www.cbd.int/gspc/

Chapin, F. S., III, G. P. Kofinas, and C. Folke. 2009. Principles of ecosystem stewardship: resilience-based resource management in a changing world. Springer-Verlag, New York, New York, USA.

da Costa, I. R., F. S. de Araújo, and L. W. Lima-Verde. 2004. Flora e aspectos auto-ecológicos de um encrave de cerrado na chapada do Araripe. Nordeste do Brasil. Acta Botânica Brasilica 18(4):759-770. http://dx.doi.org/10.1590/S0102-33062004000400006

Davidson-Hunt, I. J. and F. Berkes. 2003. Nature and society through the lens of resilience: toward a human-in-ecosystem perspective. Pages 53-82 in F. Berkes, J. Colding, and C. Folke, editors. Navigating social-ecological systems: building resilience for complexity and change. Cambridge University Press, Cambridge, UK. http://dx.doi.org/10.1017/CBO9780511541957.006

de Araujo, L. G., F. de Castro, R. R. de Freitas, M. A. R. de Mattos Vieira, and C. S. Seixas. 2017. Struggles for inclusive governance in small-scale fisheries in Paraty, southeastern coast of Brazil. Ocean and Coastal Management 150:24-34. http://dx. doi.org/10.1016/j.ocecoaman.2017.02.014

de Boef, W. S., A. Subedi, N. Peroni, M. Thijssen, and E. O'Keeffe. 2013. Community biodiversity management: promoting resilience and the conservation of plant genetic resources. Earthscan from Routledge, Oxon, UK. http://dx.doi.org/10.4324/9780203130599

de Boef, W. S., and M. H. Thijssen. 2007. Ferramentas participativas no trabalho com cultivos, variedades e sementes: um guia para profissionais que trabalham com abordagens participativas no manejo da agrobiodiversidade, no melhoramento de cultivos e no desenvolvimento do setor de sementes. Wageningen UR Centre for Development Innovation, Wageningen, The Netherlands. [online] URL: http://library.wur.nl/WebQuery/ wurpubs/fulltext/194065

Eyben, R., N. Kabeer, and A. Cornwall. 2008. Conceptualising empowerment and the implications for pro poor growth: a paper for the DAC Poverty Network. Institute of Development Studies, Brighton, UK. [online] URL: https://www.ids.ac.uk/files/dmfile/ conceptualisingempowermentpaperforPOVNET.pdf

Eyssartier, C., A. H. Ladio, and M. Lozada. 2013. Traditional horticultural and gathering practices in two semi-rural populations of Northwestern Patagonia. Journal of Arid Environments 97:18-25. http://dx.doi.org/10.1016/j.jaridenv.2013.05.008

Feitosa, I. S., U. P. Albuquerque, and J. M. Monteiro. 2014. Knowledge and extractivism of Stryphnodendron rotundifolium Mart. in a local community of the Brazilian Savanna, Northeastern Brazil. Journal of Ethnobiology and Ethnomedicine 10:64. http://dx.doi.org/10.1186/1746-4269-10-64

Ferreira Júnior, W. S., F. R. Santoro, A. L. B. Nascimento, A. H. Ladio, and U. P. Albuquerque. 2013. The role of individuals in the resilience of local medical systems based on the use of medicinal plants-a hypothesis. Ethnobiology and Conservation 2:1-10. http://dx.doi.org/10.15451/ec2013-8-2.1-1-10

Folke, C. 2006. Resilience: the emergence of a perspective for social-ecological systems analyses. Global Environmental Change 16:253-267. http://dx.doi.org/10.1016/j.gloenvcha.2006.04.002

Folke, C., S. R. Carpenter, B. Walker, M. Scheffer, T. Chapin, and J. Rockström. 2010. Resilience thinking: integrating resilience, adaptability and transformability. Ecology and Society 15(4):20. http://dx.doi.org/10.5751/ES-03610-150420

Folke, C., S. Carpenter, B. Walker, M. Scheffer, T. Elmqvist, L. Gunderson, and C. S. Holling. 2004. Regime shifts, resilience, and biodiversity in ecosystem management. Annual Review of Ecology, Evolution, and Systematics 35:557-581. http://dx.doi. org/10.1146/annurev.ecolsys.35.021103.105711

Freire, P. 1986. Educação como prática para a liberdade. Paz e Terra, Rio de Janeiro, Brazil. [online] URL: http://www.dhnet. org.br/direitos/militantes/paulofreire/livro freire educacao pratica liberdade.pdf

Freire, P. 1988. Pedagogia do oprimido. Paze Terra, Rio de Janeiro, Brazil. [online] URL: http://www.dhnet.org.br/direitos/militantes/ paulofreire/paulo freire pedagogia do oprimido.pdf

Fundação Cultural Palmares. 2018. Certificação Quilombola 2018. Fundação Cultural Palmares, Brasilia, Brazil. [online] URL: http://www.palmares.gov.br/sites/mapa/crqs-estados/crqsSc-04122018.pdf

Goldstein, B. E. 2008. Skunkworks in the embers of the Cedar fire: enhancing resilience in the aftermath of disaster. Human Ecology 36:15-28. http://dx.doi.org/10.1007/s10745-007-9133-6

Gómez-Baggethun, E., S. Mingorría, V. Reyes-García, L. Calvet, and C. Montés. 2010. Traditional ecological knowledge trends in the transition to a market economy: empirical study in the Doñana Natural Areas. Conservation Biology 24(3):721-729. http://dx.doi.org/10.1111/j.1523-1739.2009.01401.x 
Gutiérrez, N. L., R. Hilborn, and O. Defeo. 2011. Leadership, social capital and incentives promote successful fisheries. Nature 470:386-389. http://dx.doi.org/10.1038/nature09689

Healy, S. 2006. Cultural resilience, identity and the restructuring of political power in Bolivia. In 11th Biennial Conference of the International Association for the Study of Common Property; Bali, Indonesia. https://dlc.dlib.indiana.edu/dlc/bitstream/handle/10535/1488/ Healey susan.pdf? sequence $=1$ \&isAllowed $=y$

Hewlett, B. S., and L. L. Cavalli-Sforza. 1986. Cultural transmission among Aka pygmies. American Anthropologist 88:922-934. http://dx.doi.org/10.1525/aa.1986.88.4.02a00100

Hospital de Laguna. 2015. Histórico. Hospital de Laguna, Laguna, Santa Catarina, Brazil. [online] URL: http://www. hospitallaguna.com.br/hcsbjp/historico

Hospital São Francisco de Assis. 2015. Histórico do Hospital São Francisco de Assis. Hospital e Maternidade São Francisco de Assis, Crato, Brazil. [online] URL: http://www.saocamilocrato. org.br/institucional/historico-do-hospital

Imperial Hospital de Caridade. 2015. História. Imperial Hospital de Caridade, Florianópolis, Santa Catarina, Brazil. [online] URL: http://www.hospitaldecaridade.com.br/a-irmandade/sua-historia/

Ladio, A. H., and M. Lozada. 2009. Human ecology, ethnobotany and traditional practices in rural populations inhabiting the Monte region: resilience and ecological knowledge. Journal of Arid Environments 73:222-227. http://dx.doi.org/10.1016/j. jaridenv.2008.02.006

Levin, S. A. 2000. Multiple scales and the maintenance of biodiversity. Ecosystems 3(6):498-506. http://dx.doi.org/10.1007/ $\underline{\mathrm{s} 100210000044}$

Lozada, M., A. Ladio, and M. Weigandt. 2006. Cultural transmission of ethnobotanical knowledge in a rural community of Northwestern Patagonia, Argentina. Economic Botany 60 (4):374-385. http://dx.doi.org/10.1663/0013-0001(2006)60[374: CTOEKI]2.0.CO;2

Lozano, A., E. L. Araújo, M. F. T. Medeiros, and U. P. Albuquerque. 2014. The apparency hypothesis applied to a local pharmacopoeia in the Brazilian northeast. Journal of Ethnobiology Ethnomedicine 10(2). http://dx.doi. org/10.1186/1746-4269-10-2

Lutrell, C., S. Quiroz, C. Scrutton, and K. Bird. 2007. Understanding and operationalising empowerment. Overseas Development Institute, London, UK. [online] URL: https://www. odi.org/sites/odi.org.uk/files/odi-assets/publications-opinion-files/5500. pdf

Marschke, M., and F. Berkes. 2006. Exploring strategies that build livelihood resilience: a case from Cambodia. Ecology and Society 11(1):42. http://dx.doi.org/10.5751/ES-01730-110142

Nguyen, K. V., and H. James. 2013. Measuring household resilience to floods: a case study in the Vietnamese Mekong River Delta. Ecology and Society 18(3):13. http://dx.doi.org/10.5751/ ES-05427-180313

Oliveira, D. R., F. E. Brito Júnior, S. A. Sampaio, J. C. Tores, A. G. B. Ramos, and A. A. Nunes. 2012. Ethnopharmacological usage of medicinal plants in genitourinary infections by residentes of Chapada do Araripe, Crato, Ceará - Brazil. Revista Brasileira de Promoção de Saúde 25(3):278-286.

Olsson, P., V. Galaz, and W. J. Boonstra. 2014. Sustainability transformations: a resilience perspective. Ecology and Society 19 (4):1. http://dx.doi.org/10.5751/ES-06799-190401

Prado, D. S., C. S. Seixas, and F. Berkes. 2015. Looking back and looking forward: exploring livelihood change and resilience building in a Brazilian coastal community. Ocean and Coastal Management 113:29-37. http://dx.doi.org/10.1016/j.

ocecoaman.2015.05.018

Reyes-García, V., S. Gallois, and K. Demps. 2016. A multistage learning model for cultural transmission: evidence from three indigenous societies. Pages 47-60 in H. Terashima, and B. S. Hewlett, editors. Social learning and innovation in contemporary hunter-gatherers. Replacement of Neanderthals by modern humans series. Springer, Tokyo, Japan. http://dx.doi. org/10.1007/978-4-431-55997-9 4

Silva, R. R. V., L. J. Gomes, and U. P. Albuquerque. 2015. Plant extractivism in light of game theory: a case study in northeastern Brazil. Journal of Ethnobiology and Ethnomedicine 11:6. http:// dx.doi.org/10.1186/1746-4269-11-6

Sousa Júnior, J. R., U. P. Albuquerque, and N. Peroni. 2013. Traditional knowledge and management of Caryocar coriaceum Wittm. (Pequi) in the Brazilian Savanna, Northeastern Brazil. Economic Botany 67(3):225-233. http://dx.doi.org/10.1007/ S12231-013-9241-8

Stone-Jovicich, S., B. E. Goldstein, K. Brown, R. Plummer, and P. Olsson. 2018. Expanding the contribution of the social sciences to social-ecological resilience research. Ecology and Society 23 (1):41. http://dx.doi.org/10.5751/ES-10008-230141

Tamayo, A. L., A. R. Mecer, J. Bamba, F. X. Wahono, V. TauliCorpuz, E. Ngiuk. 2012. Pancur Kasih empowerment movement. Tebtebba Foundation, Baguio, Philippines.

Thorkildsen, K. 2014. Social-ecological changes in a Quilombola community in the Atlantic forest of Southeastern Brazil. Human Ecology 42(6):913-927. http://dx.doi.org/10.1007/s10745-014-9691-3

Walker, B., C. S. Holling, S. R. Carpenter, and A. Kinzig. 2004. Resilience, adaptability and transformability in social-ecological systems. Ecology and Society 9(2):5. http://dx.doi.org/10.5751/ ES-00650-090205

World Health Organization (WHO). 2008. Traditional medicine. Fact sheet N134. World Health Organization, Geneva, Switzerland. [online] URL: http://apps.who.int/gb/ebwha/ pdf_files/EB134/B134_24-en.pdf

Zank, S., J. V. C. Ávila, and N. Hanazaki. 2016. Compreendendo a relação entre saúde do ambiente e saúde humana em comunidades Quilombolas de Santa Catarina. Revista Brasileira de Plantas Medicinais 18(1). http://dx.doi.org/10.1590/1983-084X/15 142

Zank, S., and N. Hanazaki. 2016. Healing faith: knowledge, learning and social relationships of healers from Araripe plateau, Brazil. Ethnobiology and Conservation 5:3. http://dx.doi. org/10.15451/ec2016-6-5.3-1-15 
Zank, S., and N. Hanazaki. 2017. The coexistence of traditional medicine and biomedicine: a study with local health experts in two Brazilian regions. PLoS ONE 12(4):e0174731. http://dx.doi. org/10.1371/journal.pone.0174731

Zank, S., N. Peroni, E. L. de Araújo, and N. Hanazaki. 2015. Local health practices and the knowledge of medicinal plants in a Brazilian semi-arid region: environmental benefits to human health. Journal of Ethnobiology and Ethnomedicine 11:11. http:// dx.doi.org/10.1186/1746-4269-11-11 